\title{
Sciendo
}

RURAL SUSTAINABILITY RESEARCH 45 (340), 2021

ISSN - 2256-0939

(c) Latvia University of Life Sciences and Technologies, all rights reserved http://www.llu.Iv/en/

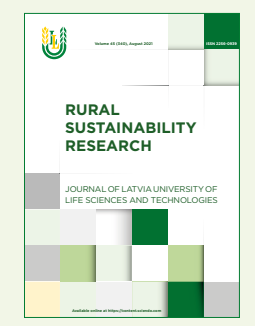

Received: 18 February 2021

Revised: 24 March 2021

Accepted: 30 April 2021

\section{Analysis of Financial Support Instruments for Social Enterprises in Latvia}

\author{
*Lasma Licite-Kurbe, Dana Gintere \\ Latvia University of Life Sciences and Technologies, Liela street 2, Jelgava, Latvia
}

\begin{abstract}
Social enterprises have positive effect on sustainable development, and they have become an important instrument for solving social problems (especially in rural areas), as the national and local governments alone cannot solve all such problems. To foster the development of social entrepreneurship, Latvia has introduced several support instruments for social enterprises, which include tax relief, privileged procurement contracts, grants, as well as non-monetary kinds of support. However, social entrepreneurs often point out that support from the national and local governments is insufficient, while the support instruments stipulated in the Social Enterprise Law are not widely used. Therefore, the aim of the research is to analyse national and local government support instruments for social enterprises in Latvia. The research found that the most important financial instrument fostering the development of social entrepreneurship in Latvia is a grant scheme administered by the Ministry of Welfare and the JSC Development Finance Institution Altum, which is available in the range of EUR 5000 to 200000 for investment and working capital. In the period 2017-2020, 94 social entrepreneurship projects with a total budget of EUR 6 million were supported, which could be viewed as significant financial support. In contrast, immovable property tax relief, exemption from enterprise income tax (on profits) and relief from this tax for several categories of non-business expenses are considered by social entrepreneurs to be an insignificant kind of support. There is also lack of experience and practice regarding the inclusion of social criteria in public procurement in Latvia.
\end{abstract}

Keywords: social enterprise, social entrepreneurship, support instruments for social enterprises.

\section{Introduction}

Social entrepreneurship is considered as a new factor in changing the objective of economic growth for sustainable development (Johnson \&, Schaltegger, 2019). It has a positive effect on sustainable development through its related activities, facilitating job creation, and, thus, increasing the aggregate demand of the economy that will stimulate economic growth and rural development (Mendez-Picazo, Galindo-Martin \& Castano-Martinez, 2020). Social entrepreneurship becomes increasingly popular in Latvia and in the world - it is a business model that allows the businesses to implement economic activity while tackling social and environmental problems relevant to the society and rural economy (Amin, 2009; Millar, Hall \& Miller, 2013; Mazzei \& Steiner, 2021). Social entrepreneurship is a way to effectively address the problems of various groups at risk of social exclusion, which in the long term can make a positive effect on the development of both the state and society. Social entrepreneurship has the potential to solve various social problems, thereby lightening the work burden on the local and national governments and reducing expenditures in local government budgets. Besides, social enterprises are often seen as more pro-active than the state at meeting social needs as they are commonly rooted within communities and can offer more flexible alternative or complementary interventions to statutory services (Nyssens, 2007; Roy et al., 2013). It could be concluded that social enterprises are important instruments for the national and local governments in tackling social problems, as the national and local governments alone cannot solve all the social problems (Dobele, 2012; Balıe, 2020); besides, social

\footnotetext{
* Corresponding Author's email: lasma.licite@1lu.lv
} 
entrepreneurs often implement social innovations in problem solving (Licite \& Grinberga-Zalite, 2018; Dobele \& Grinberga-Zalite, 2016), have a positive relationship with sustainable rural development (Johnson \& Schaltegger, 2019) and it distributes positive and sustainable outcomes to local communities and beneficiaries (Newbert \& Hill, 2014). Overall, social changes, economic problems and the demand for health care and social welfare services contribute to the development of social entrepreneurship (Doherty et al., 2009).

To date, a significant role in dealing with social problems in Latvia has been played mostly by nongovernmental organizations, which operate in the interests of society and its groups and whose activities are not profit-oriented (Bale \& Auzina, 2020). In recent years, however, many social enterprises emerged with the aim of tackling important social problems. At the end of 2020, the number of social enterprises in Latvia reached 150 (of which 140 were active social enterprises). Given that social enterprises tackle social problems important for the national and local governments, various support instruments have been developed to provide assistance to the enterprises.

In the Member States of the European Union, support for social entrepreneurship is provided by ministries and local governments, public and private financial institutions, social enterprise or social economy funds and network organizations. The kinds of support range from grants and subsidies to consultancy services provided by business incubators and business idea competitions. In addition, various kinds of support measures are targeted at both start-ups and existing social enterprises (Borzaga et al., 2020). Besides, there are various kinds of tax relief for social enterprises in the European Union: corporate income tax exemption for retained earnings, exemption from or reduction of value added tax, reduced social security costs or subsidies, as well as other kinds of tax relief that are granted to donors to organizations (Borzaga et al., 2020).

In Latvia, national support instruments for social enterprises include tax relief, preferential procurement contracts, grants as well as non-monetary kind of support, the providers of which are mostly the national and local governments. Although research studies on support instruments for social enterprises have been conducted in Latvia, (Veigure \& Zorina, 2017; Aps, Ūlande \& Lipponen, 2018; Lis et al., 2017; Līcîte, 2018; Bogane, 2020), every support instrument was not analysed in detail from the perspective of social entrepreneurs. Besides, some research studies (Bogane, 2020) concluded that social entrepreneurs believed that support from the national and local governments was insufficient, while the support instruments stipulated in the Social Enterprise Law were not widely used. Therefore, the aim of the research is to analyse national and local government support instruments for social enterprises in Latvia. It is important to provide appropriate support instruments for social enterprises because in that way it is possible to foster problem solving and sustainable development, especially in rural areas. To achieve the aim, the following specific research tasks have been set: 1) to give insight into fiscal support instruments for social entrepreneurship; 2) to describe local government support instruments for social enterprises; 3) to describe opportunities social enterprises in relation to public procurement; 4) to analyse the grant scheme for social entrepreneurship administered by the Ministry of Welfare and the JSC Development Finance Institution Altum.

In the present research, the authors focus on national and municipal financial support instruments, although social entrepreneurs could also use other available support instruments in Latvia (for example, business incubator programmes administered by the Investment and Development Agency of Latvia, programmes administered by the Rural Support Service, the State Employment Agency etc.). However, the mentioned support instruments are not analysed in detail in the research, as they are also available to ordinary entrepreneurs and therefore do not represent specific kinds of support for social enterprises. Besides, social entrepreneurs also positively view the support provided by the Latvian Social Entrepreneurship Association, as well as the fact that the social entrepreneurship accelerator New Door and the social entrepreneurship incubator Reach for Change operate in Latvia; however, these kinds of support are mainly consultative, educational and informative.

\section{Results and Discussion}

In Latvia, national support instruments for social enterprises include fiscal support instruments (enterprise income tax relief), opportunities for privileged procurement contracts, local government support instruments, as well as a grant scheme administered by the Ministry of Welfare and the JSC Development Finance Institution Altum. A summary of the support instruments is given in Table 1.

Fiscal support instruments. The Social Enterprise Law provides for a number of direct support instruments, incl. $100 \%$ exemption from enterprise income tax (EIT) if the profits are reinvested in the enterprise or allocated to a social purpose. However, in accordance with the Enterprise Income Tax Law, this condition applies not only to social enterprises but also to ordinary enterprises. Initially, the exemption from EIT was intended as a significant relief measure for social 
National and local government support instruments for social enterprises in Latvia

\begin{tabular}{|c|c|c|}
\hline Kind of support & Support provider & Challenges \\
\hline $\begin{array}{c}\text { Enterprise income tax (EIT) relief } \\
\text { (EIT is not paid because the profit } \\
\text { is reinvested in the social } \\
\text { enterprise) }\end{array}$ & Ministry of Welfare & $\begin{array}{l}\text { - The relief also applies to ordinary enterprises if } \\
\text { they do not distribute profits in dividends and is } \\
\text { therefore not a motivating factor for social } \\
\text { enterprises; } \\
\text { - Social enterprises often suffer losses; therefore, } \\
\text { the EIT relief is not an important support } \\
\text { instrument for them. }\end{array}$ \\
\hline $\begin{array}{l}\text { Enterprise income tax relief for } \\
\text { certain categories of non-business } \\
\text { expenses (as defined in Section } 8 \\
\text { of the Social Enterprise Law) }\end{array}$ & Ministry of Welfare & $\begin{array}{l}\text { - These categories of expenses are insignificant; } \\
\text { - Social entrepreneurs do not use this kind of } \\
\text { relief because of lack of understanding of how } \\
\text { to apply it to a particular enterprise; } \\
\text { - There are often insufficient financial resources } \\
\text { to implement the mentioned activities. }\end{array}$ \\
\hline Immovable property tax relief & Local governments & $\begin{array}{l}\text { This kind of support is rarely important for any } \\
\text { social entrepreneur, as most of the entrepreneurs } \\
\text { do not have their own real estate. }\end{array}$ \\
\hline $\begin{array}{l}\text { Transfer of movable property of a } \\
\text { public person to the ownership of } \\
\text { a social enterprise free of charge }\end{array}$ & $\begin{array}{l}\text { Public persons (e.g. } \\
\text { a municipality) }\end{array}$ & There is no information on such cases. \\
\hline $\begin{array}{l}\text { Transfer of public property to a } \\
\text { social enterprise for use free of } \\
\text { charge }\end{array}$ & $\begin{array}{l}\text { Local governments, } \\
\text { the national } \\
\text { government or a } \\
\text { capital company }\end{array}$ & $\begin{array}{l}\text { - Local governments have not been informed } \\
\text { about such an opportunity; } \\
\text { - Municipalities do not have suitable premises to } \\
\text { be transfered to social entrepreneurs. }\end{array}$ \\
\hline $\begin{array}{l}\text { Preferential procurement contracts } \\
\text { (Section } 16 \text { of the Public } \\
\text { Procurement Law stipulates that } \\
\text { there are two kinds of preferential } \\
\text { procurement contracts: } \\
\text { - Section } 16(1) \text { employees - } \\
\text { persons with disabilities; } \\
\text { - Section } 16(2)-\text { social } \\
\text { enterprises) }\end{array}$ & Ministry of Finance & $\begin{array}{l}\text { - The meaning of the term social criteria in } \\
\text { relation to public procurement is often limited to } \\
\text { national social security tax payments; } \\
\text { - Local governments and national institutions } \\
\text { often do not know how to use social criteria; } \\
\text { therefore, they are not used; } \\
\text { - Social enterprises have little operational } \\
\text { experience and insufficient financial and human } \\
\text { resource capacity to participate in public } \\
\text { procurement. }\end{array}$ \\
\hline $\begin{array}{l}\text { Financial support (grants) under } \\
\text { the ESF project Support for Social } \\
\text { Entrepreneurship }\end{array}$ & $\begin{array}{l}\text { Ministry of Welfare } \\
\text { and the JSC } \\
\text { Development } \\
\text { Finance Institution } \\
\text { Altum }\end{array}$ & $\begin{array}{l}\text { - Long administrative process before a grant is } \\
\text { awarded; } \\
\text { - Social entrepreneurs lack experience in writing } \\
\text { a grant proposal; } \\
\text { - The grant is intended for specific goals and } \\
\text { activities. }\end{array}$ \\
\hline
\end{tabular}

\section{Source: authors' own compilation}

enterprises operating under the legal form of Ltds. However, on 1 January 2018, amendments to the Enterprise Income Tax Law came into force, allowing ordinary enterprises not to pay EIT if they do not distribute their profits or invest in the enterprises. Accordingly, the planned tax policy benefits for social enterprises lost their relevance. This was also noted by the social entrepreneurs interviewed who said that they often suffered losses and did not make any profit; therefore, the EIT relief was not relevant and applicable to them.

Nevertheless, special CIT exemptions for certain 
categories of non-economic expenses are applicable to social enterprises: 1) recreational and social inclusion measures for social enterprise employees representing the target group; 2) integration of the target group into the labour market and the improvement of their life quality; 3) acquisition of assets that contribute to the achievement of the goals set in the statute of a social enterprise; 4) social integration of the target group; 5) donations to public benefit organizations for the purposes specified in the statute of a social enterprise if the recipient of the donation has provided the donor with information on the use of the donation by the end of the reporting year (Social Enterprise Law, Section 8). However, these categories of expenses are insignificant, as social entrepreneurs tend not to use this kind of tax relief. This could be explained by the fact that social entrepreneurs often do not understand how it could be applied to their enterprises, as well as often do not have enough financial resources to implement these activities. Besides, most of the expense categories apply to target groups and, therefore, are mostly binding for work integration social enterprises. It could be concluded that this planned kind of support has not proved its effectiveness.

Municipal support instruments. Researches reveal that municipal and governmental support is decisive factor in scaling up the social impact of a social enterprise (Gupta et al., 2020). In accordance with the Social Enterprise Law, a municipality may apply immovable property tax relief as specified in the Law on Real Estate Tax; however, according to the participants interviewed, this kind of support is rarely important for any social entrepreneur, as most of them do not own real property. Besides, one of the social enterprise owners interviewed, who owned real estate, was not informed about such an opportunity, while another interviewee who wrote an application to the municipality and requested it to reduce or cancel the rent, was refused the relief - the explanation was that 'exemption from rent may be obtained if the merchant (lessee) does not use the premises for economic activity'. This indicates that local governments often do not have an understanding of what distinguishes an ordinary limited liability company from a limited liability company having social enterprise status.

In accordance with the Social Enterprise Law, local governments may also support social enterprises in other ways, incl. granting free use of municipal property as well as granting movable property (e.g. furniture or equipment) of a public person, which may be transferred to the ownership of a social enterprise free of charge. As regards the transfer of movable property to other owners free of charge, the social entrepreneurs interviewed did not consider this kind of support to be significant, and the experts noted that there was no information on such cases. However, with regard to granting free use of premises, the social entrepreneurs interviewed noted several positive cases of cooperation between social entrepreneurs and municipalities, where a municipality granted free use of premises (e.g. in Sigulda, Riga). In Latvia, a positive example is Ogre municipality, which transferred its real estate to a social enterprise for use free of charge for setting up a café. However, the research also identified some negative cases where a municipality refused such support, as well as there were situations in which a municipality simply did not have suitable premises to be allocated to a social entrepreneur (the premises were in poor condition or their location was not acceptable for the social enterprise business idea).

Overall, the transfer of property for use free of charge is an important form of support in fostering social entrepreneurship, yet it is necessary to increase cooperation between local governments and social entrepreneurs, as well as educate local government representatives about the support instruments at their disposal, as sometimes they are not able to distinguish social enterprises from ordinary Ltds and are not aware of the support instruments they are entitled to apply to social enterprises. Besides, it is also important to motivate local governments to develop new kinds of support, e.g. grant programmes for social entrepreneurs, develop binding rules for rent relief for social enterprises, etc.

Preferential procurement contracts. Public procurement is an effective instrument for achieving the strategic goals of Latvia, as it is an opportunity to use available public resources wisely and efficiently in dealing with the common social challenges of society and the state. However, Latvia lacks experience in including social criteria in public procurement. The inclusion of social criteria in public procurement procedures could help to integrate and support vulnerable groups. The inclusion of social criteria in public procurement is allowed by legal documents (Directive 2014/24/EU, which have been transposed into the Public Procurement Law); however, the social criteria are not widely used in public procurement procedures in Latvia. Municipalities and public authorities usually do not know how to use social criteria and therefore do not use them, thereby reducing the opportunities for social enterprises to participate in the public procurement system. Usually, the cheapest tenders still dominate in public procurement.

Overall, social criteria could be theoretically divided into two categories relating to preferential contracts and social clauses. According to Section 16 of the Public Procurement Law, there are two kinds of preferential procurement contracts with regard to:

- Paragraph 1 of Section 16: employees - persons 
with disabilities. Within the scope of the measures intended for certain groups of persons, the contracting authority is entitled to reserve the right to participate in public procurement for an enterprise in which more than $30 \%$ of the average number of employees per year are persons with disabilities. Latvia has transposed the optional provision of Article 20 (1) of Directive $2014 / 24 / E U$ in relation to persons with disabilities only. The Directive provides for the possibility for the contracting authority to reserve such privileged rights also for disadvantaged persons and to 'sheltered workshops'. A shortcoming of the legal act is that there is no single database or register to verify whether the enterprise employs at least $30 \%$ persons with disabilities (on condition that the subject-matter of a procurement contract allows for it). In the conditions in Latvia, it would be more practical to replace this provision of the law with the one pertaining to work integration social enterprises. This would also mean that other social risk groups stipulated in Cabinet Regulation No. 173 Regulations regarding Population Groups at Risk of Social Exclusion and Procedures for Granting, Registering and Supervising Social Enterprise Status are also included in the law.

- Paragraph 2 of Section 16: social enterprises. Social enterprises must meet the following characteristics: 1) Ltd; 2) social enterprise status (granted by the Ministry of Welfare); 3) economic activity that creates favourable social impacts provision of social services, promotion of education or support to science, protection and preservation of the environment, provision of cultural diversity etc.; 4) an objective defined in the statute of a social enterprise involves employing a target group.

The contracting authority has the right (possibility) to reserve the right to participate in public procurement only for social enterprises if the contract is concluded for certain social, health and cultural services covered by specific CPV codes (stipulated in Section 16 (2) of the Public Procurement Law), most of which pertain to the medical and health industries. However, few social enterprises are engaged in this field. Besides, the contracting authority may take into account NACE 2 codes for enterprises to determine which social enterprises are covered by the CPV codes, yet this is burdensome and non-transparent and also does not encourage contracting authorities to launch a call for tenders.

A positive development in the field of public procurement for social enterprises was the development of Guidelines for the Implementation of Socially Responsible Public Procurement (2020). However, it should be noted that, in general, participation in public procurement is constrained by the limited experience of social enterprises, i.e. most social enterprises are small and new enterprises, and their financial performance indicators (turnover, profit) are not high. Nevertheless, social enterprises can be good and reliable partners for companies that want to be socially responsible. Consequently, social enterprises can participate independently in public procurement, or in cooperation with an ordinary enterprise.

The authors found that social entrepreneurs appreciated the important role of national and local government institutions in placing orders with social entrepreneurs. In practice, such cooperation is usually implemented through the purchase of social services, incl. from social enterprises. However, such practices could also be applied to procuring educational, cultural and art and other services and various goods. It should be noted that the research also found that some municipalities (especially their social services) regarded social entrepreneurs not as potential cooperation partners but as competitors in the supply of social services. The head of the Latvian Social Entrepreneurship Association emphasized that in the future, this kind of support needs to be increased, i.e. both socially responsible public procurement as a whole and privileged procurement. She added that in the field of public procurement, it is necessary to educate social enterprises so that they understand how to participate in public procurement, as well as to build up their capacity to participate in it. In addition, it is also necessary to educate customers - national institutions, local governments and the private sector.

Grants. Researches reveal that grant funding sources are common and important feature of social enterprises (Morales et al., 2021). In Latvia, social entrepreneurs are entitled to apply for a grant under the ESF project Support for Social Entrepreneurship, which is administered by the Ministry of Welfare in cooperation with the JSC Development Finance Institution Altum (hereinafter referred to as a grant). In 2015, Cabinet Regulation 467 Operational Programme for Growth and Employment and implementation rules for specific support objective 9.1.1 Increasing the Integration of Disadvantaged Unemployed Individuals into the Labour Market, measure 9.1.1.3 Support for Social Entrepreneurship were adopted, while the real implementation of the measure began in 2017.

The amount of the grant is in the range of EUR 5-200 thou. for investments and current assets (incl. remuneration costs). The amount of this support depends on the age of the social enterprise and the amount of its economic activity. Social enterprises with a duration of up to 3 years are entitled to apply for a grant in the range of EUR 5-50 thou., while older enterprises may receive a grant of up to EUR 200 thou.

As noted by the experts in the interviews, the grant has provided a great opportunity for the creation and 
development of a social entrepreneurship environment in Latvia. In Latvia, it is an important opportunity for social enterprises to use funding for the expansion of their activities (for existing enterprises), as well as for start-ups to start their operations in this niche. The social entrepreneurs who had used the opportunities of the grant unequivocally emphasized that it was significant financial support for the establishment or development of their social enterprises; many admitted that without it, their ideas would probably not have been implemented at all or it would take a very long time to do it.

The grant is used for various purposes. In principle, it is intended for long-term tangible investments (purchase of new equipment, devices, and vehicles), intangible investments (licenses, software, and patents). In the interviews, several entrepreneurs emphasized that it was the grant that enabled them to purchase fixed assets, while in the case of work integration social enterprises (but not only), salaries as well as employee training were also important. Other social enterprises used the grant for their complex development - for remuneration, development of IT systems, marketing and communication, as well as long-term investments. According to the entrepreneurs, the benefit of the grant is not only measurable in financial terms but it has helped entrepreneurs to build up their knowledge in finance and management, thereby more successfully developing and managing the overall operation of their enterprises. Statistical data on the grants awarded in Latvia are summarized in Table 2.

According to the information provided by the JSC Development Finance Institution Altum, as at 15/12/2020 the number of grant proposals submitted reached 198 , and 97 grants were awarded (which means that on average every second social entrepreneur was awarded a grant after assessing the eligibility for the grant), and
94 contracts with a total value of EUR $6 \mathrm{mln}$. were concluded.

At the end of 2017, the first and only recipient of a grant was the social enterprise BlindArt, while social entrepreneur activity in 2018 was very high, especially at the end of the year when the deadline for submitting grant proposals under the above-mentioned measure for social enterprises (incl. associations, foundations) expired. Out of a total of 90 grant proposals, the majority (69) were those applying for a grant under the measure. In 2019, eight more grants were awarded under the measure, while many were also rejected. Most of the entities that were awarded a grant were already social enterprises (19), while many of them were start-ups, which could apply for only a maximum of EUR 20 thou. As a result, the total amount of grants awarded in 2019 decreased by EUR 1.4 million compared with the previous year, and the average grant amount decreased from EUR 79 thou. in 2018 to EUR 52 thou. in 2019 because in 2019 a grant could be awarded only to social enterprises (Ltds that had social enterprise status).

The year 2020 was very productive in terms of awarding grants, as 38 grants were awarded and 36 grant contracts were concluded (or an average of 3 per month) until 15/12/2020. The high activity was largely due to the large number of enterprises that had and continued to have social enterprise status. In addition, a positive effect was made by amendments to Cabinet Regulation No. 467 Operational Programme for Growth and Employment and the implementation rules for specific support objective 9.1.1 Increasing the Integration of Disadvantaged Unemployed Individuals into the Labour Market, measure 9.1.1.3 Support for Social Entrepreneurship (21 May 2020), enabling any enterprise with a duration of up to 3 years to apply for a grant of up to EUR 50 thou. As a result, the average amount of grants awarded in the second

Statistics on social entrepreneurship grants in Latvia in 2017-2020

\begin{tabular}{|l|c|c|c|c|c|c|}
\hline \multicolumn{1}{|c|}{ Indicators } & $\mathbf{2 0 1 7}$ & $\mathbf{2 0 1 8}$ & $\mathbf{2 0 1 9}$ & $\mathbf{2 0 2 0}$ & Total & $\mathbf{2 0 2 0 / 2 0 1 8 , ~ \% ~}$ \\
\hline Number of grant proposals submitted & 8 & 90 & 42 & 58 & 198 & -35.6 \\
\hline Number of grants awarded & 1 & 31 & 27 & 38 & 97 & 22.6 \\
\hline Amount of grants awarded (million EUR) & 0.02 & 2.4 & 1.4 & 2.4 & 6.22 & 0 \\
\hline Number of concluded contracts & NA & 30 & 28 & 36 & 94 & 20 \\
\hline Amount of concluded contracts (million EUR) & NA & 2.3 & 1.6 & 2.1 & 6.0 & -8.7 \\
\hline Grants awarded (million EUR) & NA & 1.1 & 1.54 & 1.5 & 4.14 & 36.4 \\
\hline
\end{tabular}

Source: authors' calculations based on data from the JSC Development Finance Institution Altum (15/12/2020) 
half of 2020 increased to EUR 70 thou. Implementing the programme was facilitated by several large grants ranging from EUR 130 to almost 200 thou. A positive fact was that in 13 cases a grant was awarded repeatedly.

As regards the process of awarding a grant viewed from the perspective of social entrepreneurs, the interviewees indicated that this process was bureaucratic and long. Given that the process of assessing a grant proposal was bilateral - social impacts were analysed and assessed by the Ministry of Welfare, while the economic viability of the project was assessed by the JSC Development Finance Institution Altum. On average the process lasted for three months. Besides, the process was often prolonged due to the fact that applicants had submitted incomplete grant proposals, as a result of which it was necessary to process them several times.

Writing a grant proposal itself was one of the biggest challenges for social entrepreneurs. Often social entrepreneurs hired a financial consultant that helped to write a grant proposal, as any small enterprise most often did not have any experience in making large-scale business plans. A positive fact was that the employees of the JSC Development Finance Institution Altum advised social entrepreneurs on writing a grant proposal. Despite the fact that the JSC Development Finance Institution Altum summarized the main challenges in writing grant proposals, e.g. the kind of economic activity specified in the application did not match the one specified when the enterprise was granted social enterprise status, business project costs were not directly linked with the business project plan, specific countable/measurable indicators of expected social impacts were not defined, the particular site of implementation of the project was not specified, eligible VAT costs were incorrectly indicated, as well as the conflict of interests was not eliminated when selecting suppliers.

According to an expert from the JSC Development Finance Institution Altum, they supported only economically justified and viable business projects, yet this was often the biggest challenge for the social enterprises. Another well-known challenge was the fact that there were certain costs that may not be covered by the grant, which could seem important to the social entrepreneur (incl. purchase of buildings and land, repair or renovation of rooms or buildings, construction etc.). The ESF does not fund anything related to construction, real property development, infrastructure and land acquisition.

\section{Conclusions}

1. The Social Enterprise Law provides for a number of direct support instruments for social enterprises, incl. $100 \%$ exemption from enterprise income tax if the profits are reinvested in the enterprise or allocated to a social purpose. However, the social entrepreneurs interviewed believed that this was not an important kind of support, as social enterprises usually made little profits or suffered losses. As regards enterprise income tax relief for certain categories of noneconomic expenses, it was found that the categories of expenses incorporated in the Social Enterprise Law were insignificant, and social entrepreneurs did not use this kind of relief. This could be explained by the fact that social entrepreneurs often do not understand how it would be applied to a particular enterprise, as well as often did not have enough financial resources to implement the activities.

2. A municipality may apply real estate tax relief to social enterprises, but any social entrepreneur rarely has his or her own real estate. Municipalities could also support social enterprises by transferring their movable or real estate to the social enterprises for use free of charge. In practice, there have been positive cases where local governments transferred their premises to social enterprises, but such cooperation was often denied or the local government did not have suitable premises to be transferred to a social entrepreneur. Overall, the transfer of property to social enterprises for use free of charge is an important kind of support in promoting social entrepreneurship, yet it is necessary to increase cooperation between local governments and social entrepreneurs, as well as educate local government representatives about the support instruments at their disposal, as sometimes they are not able to distinguish social enterprises from ordinary Ltds and are not aware of the support instruments they are entitled to apply to social enterprises.

3. Social entrepreneurs appreciated the role of national and local government institutions in placing orders with social entrepreneurs. In practice, such cooperation is usually implemented through the purchase of social services, incl. from social enterprises. However, such practices could also be applied to procuring educational, cultural and art, and other services as well as goods.

4. In the field of public procurement in Latvia, there is a lack of experience in including social criteria in public procurement. Municipalities and public authorities usually do not know how to use social criteria and therefore do not use them, thereby reducing the opportunities for social enterprises to participate in the public procurement system. Besides, participation in public procurement is constrained by the limited experience of social enterprises, i.e. most social enterprises are small and new enterprises and lack financial and human resource capacity. 
5. The most important financial instrument for the development of social entrepreneurship in Latvia is a grant scheme administered by the Ministry of Welfare and the JSC Development Finance Institution Altum, which is available in the range of EUR 5-200 thou. for investments and current assets (incl. remuneration costs). The amount of this support depends on the age of the social enterprise and the amount of its economic activity. Although social entrepreneurs considered the process of awarding a grant award to be relatively long and writing a grant proposal was complicated, 97 projects were supported in four years, and 94 grant contracts with a total value of EUR 6 million were concluded, which could be viewed as a positive result.

\section{References}

Amin, A. (2009). The Social Economy. International Perspectives on Economic Solidarity. London: Zed Books.

Aps, J., Ūlande, M., \& Lipponen, K. (2018). Social Impact Investment in the Nordic-Baltic Region: Ideas and Opportunities, Needs and Challenges Using Examples from Estonia, Latvia and Finland. Nordic Council of Ministers' Office in Estonia.

Bal̦e, I. (2020). Sociālā uzņēmējdarbība kā nevalstisko organizāciju darbības attīstības instruments: biedrības 'Oranžais stars' piemērs (Social Entrepreneurship as an Instrument for the Development of Non-Government Organizations' Activities: a Case Study of the Association 'Oranzais stars'). Master Thesis, Latvia University of Life Sciences and Technologies, Jelgava, Latvia. (in Latvian).

Bale, I., \& Auzina, A. (2020). Social Entrepreneurship as an Instrument for the Development of Non-government Organization's Activities: A Case Study of the Association 'Oranzais Stars'. In Proceedings of the 2020 International Conference 'Economic Science for Rural Development', No 54, 12-15 May 2020 (pp. 141-150). Jelgava, Latvia: LLU ESAF. DOI: 10.22626/ESRD.2020. 53.016.

Bogane, I. (2020). Izaicinājumi sociālās uzñēmējdarbības attīstībai Latvijā (Challenges for the Development of Social Entrepreneurship in Latvia). Master Thesis, University of Latvia, Riga, Latvia. (in Latvian)

Borzaga, C., Galera, G., Franchini, B., Chiomento, S., Nogales, R., \& Carini, C. (2020). Social Enterprises and Their Ecosystems in Europe. Comparative Synthesis Report. Luxembourg: Publications Office of the European Union.

Dobele, L. (2012). Social entrepreneurship paradigm and its assessment in Latvia. In Proceedings of the International scientific conference 'Economic Science for Rural Development', No 27, 26-27 April 2012 (pp. 55-63). Jelgava, Latvia: Latvia University of Life Sciences and Technologies. Faculty of Economics and Social Development.

Dobele, L., \& Grinberga-Zalite, G. (2016). Opportunities of Integrating Social Awareness in Higher Education to Enhance the Development of Social Innovation in Latvia. In $16^{\text {th }}$ International multidisciplinary scientific GeoConference SGEM 2016, Ecology, Economics and Legislation, Book 5, Volume 3: Environmental Economics Education and Accreditation in Geosciences, 30 June - 6 July 2016 (pp. 915-922). Albena, Bulgaria: Bulgarian Academy of Sciences Sofia

Doherty, B., Foster, G., Mason, C., Meehan, J., Meehan, K., Rotheroe, N., \& Royce, M. (2009). Management for Social Enterprise. London: SAGE publications.

Gupta, P., Chauhan, S., Paul, J., \& Jaiswal, M.P. (2018). Social entrepreneurship research: A review and future research agenda. Journal of Business Research, 113, 209-229. DOI: /10.1016/j.jbusres. 2020.03.032

Johnson, M.P., \& Schaltegger, S. (2019). Entrepreneurship for sustainable development: A review and multilevel causal mechanism framework. Entrepreneurship Theory and Practice, 44(6), 1141-1173. DOI: 10.1177/1042258719885368.

Licite, L., \& Grinberga-Zalite, G. (2018). Social entrepreneurship and social innovation: theoretical discourse. In Proceedings of the International scientific conference 'Economic Science for Rural Development', No. 49, 9-11 May 2018 (pp. 341-348). Jelgava, Latvia: Latvia University of Life Sciences and Technologies. Faculty of Economics and Social Development.

Lìcite, L. (2018). Up-date of the Mapping of Social Enterprises and Their Eco-systems in Europe. Country Report Latvia. Luxembourg: Publications Office of the European Union.

Lis, A., Wallberg, N., Nordstrom, T., Šuvajevs, A., \& Ūlande, M. (2017). Sociālie uzñèmumi un pašvaldības: Sadarbība, partnerība un sinergíija (Social Enterprises and Municipalities: Cooperation, Partnership and Synergy). Nordic Council of Ministers. (in Latvian)

Mazzei, M., \& Steiner, A. (2021). What about Efficiency? Exploring Perceptions of Current Social Enterprise Support Provision in Scotland. Geoforum, 118, 38-46. DOI: 10.1016/j.geoforum. 2020.12.002.

Mendez-Picazo, M.T., Galindo-Martin, M.A., \& Castano-Martinez, M.S. (2020). Effect of 
sociocultural and economic factors on social entrepreneurship and sustainable development. Journal of Innovation \& Knowledge, 6, 69-77. DOI: $10.1016 /$ j.jik.2020.06.001.

Millar, R., Hall, K., \& Miller, R. (2013). A Story of Strategic Change: Becoming a Social Enterprise in English Health and Social Care. Journal of Social Entrepreneurship, 4(1), 4-22. DOI: 10.1080/ 19420676.2012.69437.

Morales, A., Calvo, S., Guaita Martinez, J.M., \& Martin Martin, J.M. (2021). Hybrid forms of business: Understanding the development of indigenous social entrepreneurship practices. Journal of Business Research, 124, 212-222. DOI: $10.1016 /$ j.jbusres. 2020.11.060.

Newbert, S.L., \& Hill, R.P. (2014). Setting the stage for paradigm development: A 'small-tent' approach to social entrepreneurship. Journal of Social Entrepreneurship, 5(3), 243-269. DOI: 10.1080/ 19420676.2014 .889738$.

Nyssens, M. (2007). Social Enterprise: At the Crossroads of Market, Public Policies and Civil Society. London, UK: Routledge.

Roy, M.J., Donaldson, C., Baker, R., \& Kay, A. (2013). Social Enterprise: New Pathway to Health and Wellbeing? Journal of Public Health Policy, 34(1), 55-68. DOI: 10.1057/jphp.2012.61.

Veigure, A., \& Zorina, A. (2017). The Potential for Developing a Social Impact Investment Market in Latvia. Executive Master Thesis, SSE Riga, Riga, Latvia. 